\title{
Cities Through the Ages: One Thing or Many?
}

\author{
Michael E. Smith ${ }^{1 *}$ and José Lobo ${ }^{2}$ \\ ${ }^{1}$ School of Human Evolution and Social Change, Arizona State University, Tempe, AZ, United States, ${ }^{2}$ School of \\ Sustainability, Arizona State University, Tempe, AZ, United States
}

The variability among cities, from the ancient world to the present, can be organized usefully in two ways. First, a focus on the dominant urban activities and processes leads to the recognition of two basic urban types: economic cities and political cities. Most cities today are economic cities in which growth proceeds through agglomeration processes. By contrast, most cities in the ancient world (and some today) are political cities, in which power and administration play a major role in structuring cities and generating change. Second, an alternative focus on processes of social interaction within the urban built environment leads to the recognition that there is only one kind of settlement that includes all cities-economic and political; past and present. Cities in this sense are settings for "energized crowding." Processes of interaction generate both economic and political growth, and they produce and influence the built forms and social characteristics of all cities. Our model helps scholars distinguish the unique from the universal traits of

OPEN ACCESS

Edited by:

Francesca Fulminante, University of Bristol, United Kingdom

Reviewed by:

Douglas Gollin, University of Oxford, United Kingdom Stephen A. Kowalewski, University of Georgia, United States

${ }^{*}$ Correspondence: Michael E. Smith mesmith9@asu.edu

Specialty section: This article was submitted to Digital Archaeology, a section of the journal Frontiers in Digital Humanities

Received: 24 October 2018 Accepted: 22 May 2019 Published: 06 June 2019

Citation:

Smith ME and Lobo J (2019) Cities Through the Ages: One Thing or Many? Front. Digit. Humanit. 6:12. doi: 10.3389/fdigh.2019.00012 cities today and in the past.

Keywords: cities, agglomeration, growth, comparative analysis, networks, scaling, social interactions

\section{INTRODUCTION}

Cities today are both the engines of innovation and economic growth, and the settings for concentrated social problems. As cities around the world expand in size and impact, advances in the scientific understanding of cities, urbanism, and urbanization take on increasing urgency. Do fundamental urban processes exist that generate a basic kind of city, in whatever context or culture or time period? Or are the expressions of urbanism too diverse to include in a single model? Is contemporary urbanization simply an elaboration upon past urbanization processes, or is it a fundamentally different kind of process?

Urbanization through the ages has manifested an enormous variation in the spatial and social forms of cities, their size, functions, activities, and growth patterns. Given this great variability in so many domains, it is not hard to argue that any notion of a single urban form or process or pattern throughout history must involve over-simplification. The differences among cities, across space and time, would seem too great to fit into a single type or model. Nevertheless, scholars in a variety of disciplines have argued that cities-regardless of their size, geography, temporal setting, or cultural milieu-share many underlying social characteristics, and play similar functional roles in different human societies (Mumford, 1961; Jacobs, 1969; Hall, 1998). There is a growing recognition that human settlements from Ur to Mumbai share enough in common that the term "cities" can be used to meaningfully refer to entities separated by thousands of years (Algaze, 2008; Smith, 2010b; York et al., 2011; Barthel and Isendahl, 2013). Yet this work has failed to specify just what characteristics of cities through the ages allow them to be considered or analyzed as a single phenomenon, in spite of their obvious differences. 
Cities (and human settlements more generally) are essentially about the advantages afforded by aggregation which in turn are a manifestation of human sociality (Boyd and Richerson, 2005). Population size is both a major determinant and consequence of social evolution (Henrich, 2015). The basic demographic dynamics of expansion, maintenance, and decline are essential to cities, ancient, pre-modern, and modern. Over their existence all cities documented by archaeology and history went through phases of expansion (in spatial extension and population size) before eventually declining. The existence, extent, and relevance of economic growth (which can mean either increases in material output or increases in output per capita) in ancient and premodern societies is a topic of considerable debate (Erdkamp, 2016; Jongman, 2016; Stark et al., 2016),(Greene, 2000; Scheidel, 2004; Pryor, 2005). The reality of urban growth, on the other hand (either an increase in the proportion of a society's population residing in urban settlements or the increase in the population size of individual urban settlements), in ancient and pre-modern societies is not. Understanding what is common and what is not with regards to urban (population) growth across time is key to understanding what is common to urban life across eras and civilizations.

The question posed in our title-one thing or many?-has two answers. First, when we focus on the institutional framework of cities, including the mechanisms that generate urban growth, there are two fundamentally different forms of cities. We call these economic cities and political cities. In urban economics, this contrast is often discussed in terms of differences between "normal" cities and primate cities (de Long and Shleifer, 1993; Ades and Glaeser, 1995), but in fact the distinction runs deeper than this. Most cities before the modern era were political cities, meaning that their dominant institutions were in the realms of power and administration by a ruler or ruling elite. A few premodern cities and most cities today are economic cities, meaning that economic considerations dominate the locational decisions of individuals and production units, and that economic activities largely shape their social structure and economic forces dominate their processes of growth.

Notwithstanding the very real and important differences between economic cities and political cities, urban growth in both types originates in a common set of behavioral and builtenvironmental mechanisms that underlie both the economic and political drivers normally discussed in the urban literature. A focus on these fundamental mechanisms leads to our second answer to the question of "one thing or many?": the city is one thing amidst a plurality of manifestations of urban life. It is a place of energized crowding (Kostof, 1991, p. 37) that generates growth and change (Smith, 2019). These underlying mechanisms have been explored by several strands of recent work that take the perspective-theoretically grounded and empirically supported-that cities are, and have been, social networks of people embedded in physical space (Fisher, 2009; Hipp et al., 2012; Bettencourt, 2013; Youn et al., 2016). This body of research has revived the prospects for building an analytical framework for understanding the origins and drivers of urbanization operating in cities from the distant past and contemporary urban life, both economic, and political cities.
Our dual answer to the question of "one thing or many?" has implications for understanding cities and urbanism today. Whether one is interested in identifying universal urban traits (Smith et al., 2015), tracing the development of urbanism over time (Mumford, 1961), or using ideas from past cities to inform contemporary practice (Rapoport, 1973; Hakim, 2012), it is important to understand both the continuities and disjunctions between cities today and those of the past. Are the principles of the new urbanism (Congress for the New Urbanism, 1996) based on universal urban realities, or do they only reflect conditions of the very recent past? How can scholars predict whether current principles of urban resilience will play out over long periods of time? We propose that our formulation of cities through the ages can help frame analyses of these and other questions about cities and urban life in the present and future.

\section{WHAT IS A CITY?}

In his book Triumph of the City, urban economist Edward Glaeser defines cities as "the absence of physical space between people and companies. They are proximity, density, closeness" (Glaeser, 2011, p. 6). Glaeser's minimalist definition does seem to capture what for many is the essential feature of cities. Yet its very minimalism allows the definition to apply equally to every form of human settlement-from hunter-gatherer camps to cities-in which physical proximity facilities social life. Furthermore, high density is no longer characteristic of all modern cities (Angel, 2012), nor was it characteristic all ancient cities (Fletcher, 2009).

Archaeologist [Cowgill (2004), p. 526] observed that, "It is notoriously difficult to agree on a cross-culturally applicable definition of "the" city, but we cannot do without definitions altogether.... No single criterion, such as sheer size or use of writing, is adequate." The urban literature reveals two dominant approaches to city definition: a sociological/demographic approach and a functional approach. The most influential definition is that offered by sociologist [(Wirth, 1938), p. 8]: "For sociological purposes a city may be defined as a relatively large, dense, and permanent settlement of socially heterogeneous individuals." This definition clearly fits contemporary cities, and it is favored by most scholars of urbanism today. But historians, anthropologists, and archaeologists have pointed out that the sociological definition excludes most pre-modern cities from consideration as urban settlements (e.g., Sjoberg, 1960; Fox, 1977; Smith, 2016).

Early urban settlements were prominent and influential within their regional settings, yet their levels of population size, density, and heterogeneity were considerably lower than contemporary western cities. This situation led to the adoption of a "functional" approach to definition, based on work in economic geography (Lloyd and Dicken, 1972). The definition of archaeologist [Trigger (1972), p. 577] is typical: "It is generally agreed that whatever else a city may be it is a unit of settlement which performs specialized functions in relationship to a broad hinterland." An urban function is an activity or institution that directly affects life and society in a hinterland. The initial 
functional definition of cities focused on retail economic functions, and central place theory provided concepts and methods for understanding cities as economic central places (Christaller, 1966). Anthropologists then moved beyond economic functions to define cities using other regional impacts such as political administration or religion (Fox, 1977; Marcus, 1983).

While these sociological and functionalist urban definitions have often been opposed to one another and treated as alternative approaches, we wish to highlight an important commonality. Both definitions encompass the idea that social interactions within a delimited space are important drivers of the urbanization process. In the words of architectural historian [Kostof (1991), p. 37], "Cities are places where a certain energized crowding of people takes place." That is, cities are settings for frequent and intense social interactions, and by implication these interactions have important effects on urban behavior and output (Smith, 2019). The density and social heterogeneity of Wirth's urban concept imply the importance of that energized crowding. And the urban functions of the alternative definition are nothing more than specific kinds of social interactions that generate the influence a city has on its hinterland. This notion of "energized crowding" is also the theoretical foundation of our discussion below of the city as many things at once, or, in effect "the city as one thing."

\section{THE CITY AS TWO THINGS: ECONOMIC AND POLITICAL CITIES}

Most cities before the Industrial Revolution were political cities and most contemporary cities are economic cities. This dichotomy is based on the nature of economic activity, its prominence in urban dynamics, and its relationship to growth. Virtually all of the literature in urban economics and urban geography focuses on the locational choice of businesses and individuals, and on the positive externalities (due to agglomeration) to the productivity of firms and individuals. This leads contemporary work in urban economics, economic geography, and regional science to have a "modernist" bent applicable mainly to cities whose economies are productive and dynamic. In our scheme most economic cities exist within the capitalist world system, but we think that more research is needed to determine the extent to which our economic cities concept might apply to cities before the modern era. Political cities, on the other hand, are those cities in which political or administrative activities predominate. Economic processes are either suppressed by political forces (as in recent primate cities), or else are simply far less developed than in contemporary cities.

The concepts economic city and political city are Weberian ideal types: pure classifications that will never match the empirical world precisely (Gerth and Mills, 1946, p. 59, 60). They are ends of a continuum. This dichotomy is similar-but not identical-to a number of dichotomous typologies in the urban literature (Table 1). We are proposing a new dichotomy because
TABLE 1 | The city as two things: dichotomous city typologies.

\begin{tabular}{|c|c|c|c|}
\hline Political cities & $\begin{array}{l}\text { Economic } \\
\text { cities }\end{array}$ & Citations & Context \\
\hline Government towns & $\begin{array}{l}\text { Commercial } \\
\text { towns }\end{array}$ & Smith, 1979 & $\begin{array}{l}\text { Cities in Wealth of } \\
\text { Nations }\end{array}$ \\
\hline Consumer city & Producer city & $\begin{array}{l}\text { Weber, 1958; } \\
\text { Finley, } 1973\end{array}$ & $\begin{array}{l}\text { Classical vs. medieval } \\
\text { cities }\end{array}$ \\
\hline Public urbanism & $\begin{array}{l}\text { Commercial } \\
\text { urbanism }\end{array}$ & Clarke, 1993 & Roman cities in Britain \\
\hline Parasitic city & $\begin{array}{l}\text { Generative } \\
\text { city }\end{array}$ & $\begin{array}{l}\text { Hoselitz, } \\
1955\end{array}$ & $\begin{array}{l}\text { Cities in developing } \\
\text { nations }\end{array}$ \\
\hline Orthgenetic city & $\begin{array}{l}\text { Heterogenetic } \\
\text { city }\end{array}$ & $\begin{array}{l}\text { Redfield and } \\
\text { Singer, } 1954\end{array}$ & Cultural roles of cities \\
\hline Dependent economy & $\begin{array}{l}\text { Autonomous } \\
\text { economy }\end{array}$ & Fox, 1977 & World historical cities \\
\hline Primate city & $\begin{array}{l}\text { Non-primate } \\
\text { city }\end{array}$ & Various & $\begin{array}{l}\text { Deviation from Zipf's } \\
\text { law }\end{array}$ \\
\hline
\end{tabular}

none of these prior schemes are sufficiently broad to encompass the entire range of historical urbanism. ${ }^{1}$

The earliest of these ideal-type city dichotomies was Smith (1979) distinction between government towns and commercial towns (Stull, 1986). The primary activities in the former are administration and rule, which, in Smith's scheme, are considered unproductive labor. Smith describes these workers as "idle, dissolute, and poor" (Stull, 1986, p. 300). Most workers in commercial towns, in contrast, are "industrious, sober, and thriving." Adam Smith's list of eighteenth-century government towns includes Rome, Madrid, Versailles, Paris, and Edinburgh prior to 1707. Commercial towns included Glasgow, many English towns, and most Dutch towns. He classified other cities of his time as having attributes of both types: London, Lisbon, Copenhagen, and Edinburgh after 1707.

The contrast between the consumer city and producer city originated with Max Weber and other early twentieth century economic historians to contrast the ways in which Classical and medieval cities obtained food from their hinterland. Commercial enterprises in medieval producer cities allowed urbanites to obtain food from farmers through commercial exchange, whereas elites in ancient consumer cities received rural income from rents. Classicists debated which concept best fit Roman cities and towns for decades (e.g., Parkins, 1997), an argument that got tangled up with the primitivist/modernist debate on the ancient economy. Recent work has reached two conclusions: (1) markets were operational in many but not all ancient societies; and, (2) the presence of markets does not turn ancient societies

\footnotetext{
${ }^{1}$ We realize that some scholars in the humanities view typologies-particularly dichotomies-as simplistic devices that impede understanding of the rich details of individual cases. But comparative analysis and theoretical advance require simplification in order to promote understanding on a level above that of individual cases (Healy, 2017; Smith, 2018). Simplified schemes-like economic and political cities-are not intended to substitute for detailed studies of specific cases or contexts; instead, their purpose is to promote understanding and explanation. They complement detailed studies of cases.
} 
into protocapitalists entities (Morris, 2004; Feinman and Garraty, 2010; Garraty and Stark, 2010).

In a study of variation in Roman cities in Britain, Clarke (1993) evaluates several general models of the spatial organization of preindustrial cities, including Sjoberg (1960), Vance (1971), and Langton (1975). None of these models fit the Roman cities of Britain well, leading Clarke to synthesize various insights of these authors into two models that he calls, "Public urbanism" (Sjoberg's model of class-based spatial zones, with less emphasis on the commercial component) and "Commercial urbanism" (the Medieval city model of Vance, which emphasizes the importance of guilds and the lack of zoning by class).

The next two dichotomies arose in the 1950s in the literature on economic development. Economist Hoselitz (1955) classified cities as generative or parasitic if they have a positive or negative impact on economic growth in their region or country; see also Wrigley (1978). Anthropologists Redfield and Singer (1954) promoted stereotypes of developing nations in their classification of orthogenetic cities (traditional cities where the "moral order" dominates) and heterogenetic cities (modernizing cities where the "technical order" is primary). The dependent/autonomous economy dimension of Richard Fox's functional typology maps onto our political/economic dichotomy quite closely; his regalritual, administrative, and colonial cities categories fit into our political category, and his industrial and mercantile cities fit into the economic type. City-state capitals are split between the two categories; Greek, Yoruba, and Aztec examples were political cities, but many post-medieval European city-state capitals were economic cities. We also include primate cities in our political category. These are cities whose size far exceeds other cities in their regional system (Adamic, 2011). Of contemporary primate cities, [Ades and Glaeser (1995), p. 195] state, "political forces, even more than economic factors, drive urban centralization" (we discuss primate cities more fully below).

Our categories political and economic cities-like the other parallel dichotomies listed in Table $\mathbf{1}$-are Weberian ideal types that are not intended to match precisely any specific city. In fact, these categories may best be viewed as ends of a continuum rather than as a rigid dichotomy. Our purpose is to improve scholarly understanding of the variability among cities, not to categorize specific cities.

\section{Growth in Cities}

The phenomenon of growth and its drivers would seem to provide the starkest difference between ancient and modern cities. Clearly delineating these is an important part of an exercise aiming to identify commonalities across the historical experiences of urban development. We start with the question, what is economic growth? At its most basic, an increase in a society's material output with respect to a previous period is an instance of economic growth. An increase in economic output caused by more efficient use of inputs is referred to as intensive growth, while growth caused only by increases in the "factors of production" (such as labor or agricultural land) is called extensive growth (Bjork, 1999). Labor power was and remains the most important input into production, and therefore population growth alone would have sufficed, in most situations, to bring about an increase in material output in pre-modern societies (otherwise a process of immiseration would have kicked in.) "Smithian growth" refers to a situation in which growth is driven by increased labor specialization, itself facilitated by the geographical expansion of markets (Burkai, 1969; Kelly, 1997; Persson and Sharp, 2015). This type of growth required an extension of commercialization and transportation infrastructure. The Solow-Swan type models of economic growth, with their explanatory emphasis on capital accumulation and population growth, exerted great influence in the economics profession during the 1960s and 1970s (Solow, 1956; Swan, 1956). In the modern era economic growth, of the Smithian or intensive variety, has entailed increases in productivity (usually captured via measures of output per capita) so much so that-for modern economies-economic growth is tantamount to increases in productivity (Allen, 2009).

For nearly three decades now work in growth economics has been dominated by the "new economic growth theory" which emphasizes the generation and exchange of knowledge, innovation and invention, and human capital (i.e., skilled individuals) as drivers of productivity increases and growth (Lucas, 1988; Romer, 1990; Weil, 2008). The emphasis on knowledge spillovers (a form of externality) in turn gave rise to a renewed interest in the role of cities as the privileged setting for the generation and recombination of knowledge (Lucas, 1988; Glaeser, 2011). The manifestation of the "new growth theory" perspective with respect to urban development has emphasized the operation of "agglomeration economies" (Fujita et al., 1999). Agglomeration economies arise when concentrations ("agglomerations") of individuals firms, and institutions create interactions and feedback that generate non-market mediated benefits (knowledge flows, for example). These agglomeration economies are assumed to be major drivers of growth in most recent works explaining urban economic development (e.g., Black and Henderson, 1999; O'Sullivan, 2011; Storper, 2013).

Duranton and Puga (2004) divide the forces generating agglomeration into three micro-level processes: sharing, matching, and learning. Sharing refers to the presence of public goods (infrastructure, markets, and other institutions facilitating commerce) in cities, and to the gains from specialization and from larger number of suppliers that are shared among individuals and firms. Although political cities certainly offered public goods (Stanley et al., 2016), the much lower levels of technology, infrastructure, and commercialization led to lower levels of productive interaction and economic growth. Matching refers to the pairing of people and jobs that occurs in urban areas. Given the far lower prevalence of wage labor in pre-capitalist economies-coupled with the far lower level of individual specialization-it is unlikely that matching was a significant force in creating agglomeration in political cities. Learning refers to the generation, diffusion and accumulation of knowledge, particularly the education of workers that contributes to human capital in agglomeration economies. The much reduced levels of education and literacy in pre-capitalist economies renders learning a minor factor in generating change and economic growth in political cities. Storper (2013) provides a parallel discussion of the major causes of urban 
growth and agglomeration. From a broader perspective, if we consider the realm of contemporary economic growth-not just urban agglomeration-it is quite clear that most of the major processes (Jones and Romer, 2010) have few counterparts in pre-capitalist economies.

\section{Political Cities and Economic Growth in the Ancient World}

The concept of primate city in urban economics (de Long and Shleifer, 1993; Ades and Glaeser, 1995; Behrens and Bala, 2013) gets to the core of the distinction between the growth processes of political and economic cities. It is in the realm of economic growth, relentlessly present in modern social life and seemingly absent in the ancient past, that the greatest chasm between ancient and contemporary urban life is to be found. [Ades and Glaeser (1995), p. 224] summarize how primate cities differ from other cities as follows:

Urban giants ultimately stem from the concentration of power in the hands of a small cadre of agents living in the capital. This power allows the leaders to extract wealth out of the hinterland and distribute it in the capital. Migrants come to the city because of the demand created by the concentration of wealth, the desire to influence leadership, the transfers given by the leadership to quell local unrest, and the safety of the capital. This pattern was true in Rome, 50 C.E., and this description is still true in many countries today.

[de Long and Shleifer (1993)1993, p. 686] note for their historical sample that, "the presence of an absolutist prince [a marker of a primate city] reduces the growth of population in cities of more than 30,000 by nearly 180,000 people per century."

The level of commercialization in an economy provides a rough index of the scale from political to economic cities. By "commercialization" we mean the number and influence of commercial institutions in an economy. Such an index runs from uncommercialized economies that lack money, accounting systems and entrepreneurial merchants, to moderately commercialized economies (with money in the form of coinage and accounting systems, but without wage labor or banking), to highly commercialized economies (with all of these traits and others). This concept and scale is based on Smith (2004) and a series of works in economic history (e.g., Braudel, 1982; North, 1991; Temin, 2013; Persson and Sharp, 2015). ${ }^{2}$

The remarkable thing about such a this scale of commercialization is that even the most highly commercialized pre-Medieval economy-Imperial Rome-still had very limited levels of economic growth. Growth did occur in ancient Greece (Morris, 2004) and Imperial Rome (Jongman, 2012), but Roman cities were not dynamic and expanding commercial centers in the way that contemporary economic cities are. There was a real transformation between the Roman Empire and the medieval period in the nature of commercial activity and the role of cities.

\footnotetext{
${ }^{2}$ A commercialization scale was devised for a project that compared 23 premodern cities on a variety of attributes (Smith et al., 2016; Stanley et al., 2016), and I thank Barbara Stark, Benjamin Stanley, Abigail York, and Timothy Dennehy for help in constructing this commercialization scale.
}

Double-entry bookkeeping, for example, did not begin its rapid expansion until around 1,500 (Gleeson-White, 2012).

Hudson (2010) pinpoints the activities, institutions, and values of the Classical world responsible for what he calls the "corrosive forms of enterprise" that dominated the economy. Rent-seeking behavior was rampant. "The oligarchic ethic preferred seizing wealth abroad to creating it at home. The major ways to make fortunes were by conquest, raiding and piracy, slave capture and slave dealing, money lending, tax farming, and kindred activities more predatory than entrepreneurial" (p. 15). Although the economy of Imperial Rome had reached the highest level of commercialization in the world prior to Medieval Europe, its economy was still "unproductive" (Baumol, 1990) in the prevalence of rent-seeking over commercial growth. In a study of Roman banking, [Andreau (1999), p. 147-48] asks, "Did Roman financiers direct most of their effort toward economic life in order to create an effective instrument for investments? Did any financial establishments specialize in the promotion of productive loans? The answer to both questions must definitely be no."

Of the Roman Empire, [Hopkins (1978), p. 77] noted, "Huge pre-industrial empires accumulate huge resources; they spend a large part of that accumulated surplus on self-preservation, not on economic growth." The implication is clear: the behaviors and institutions that produce economic growth and urban agglomeration economies in modern cities were for the most part absent from the political cities of the ancient world, and these cities require very different models of growth. In the words of historian [Noreña (2014), p. 193] "All cities in preindustrial economies are in one sense artificial, in that they depend on a set of political institutions, coercive instruments, and legitimizing mechanisms that together enable a group of non-primary producers to live off the surplus produced by peasant farmers."

\section{Agglomeration Processes in Political Cities}

Even if we acknowledge that economic growth was far less important in ancient cities than it is today, it is still useful to ask whether agglomeration economies might have generated urban growth in the political cities of the past. Virtually the entire literature on urban agglomeration is tailored for contemporary or recent historical economic cities with capitalist economies. Nevertheless, it is possible to expand the concept of urban agglomeration beyond economics to make it more applicable to pre-modern cities. This is the approach taken by several economists to explain anomalous patterns of growth in historical and contemporary primate cities (de Long and Shleifer, 1993; Ades and Glaeser, 1995). Their approach can be broadened even further by considering the spatial concentration of various kinds of non-economic activity in pre-modern cities and its effects.

Urban agglomerations of power and administration are the most obvious case, but it is not too far-fetched to suggest that ritual activity could also generate concentrations of social interactions and urban growth. Indeed, this was one component of Wheatley (1971) classic model of early urbanization. In a recent paper, [Scott and Storper (2015), p. 4] propose this kind of broader approach to agglomeration: 
Even in the very earliest cities, agglomerations of activities such as political administration, ceremonial and religious pursuits, craft production (e.g., for luxury goods or military hardware), and market trading almost always constituted the core of the urban process (Wheatley, 1971). Agglomeration occurs because activities like these entail divisions of labor and other interdependencies as expressed in transactional relationships whose costs are distance dependent and because they can reap functional synergies by clustering together in geographic space. Various types of infrastructure help to consolidate the resulting dynamic process of agglomeration. In other words, one of the central features of urbanization has always been its efficiencygenerating qualities via agglomeration.

Nevertheless, the levels of feedback and urban growth generated by these non-economic agglomeration processes seem orders of magnitude smaller than the contemporary growth processes of agglomeration in economic cities.

Scott and Storper seem to recognize the gulf between agglomeration processes in political and economic cities when they point out that early cities were "caught in a Malthusian trap" that was only overcome with the sharp rise in economic productivity with industrialization. They suggest that the Industrial Revolution was "an era where the fundamental relationship between economic development and urbanization becomes especially clear" (Scott and Storper, 2015, p. 5). But from our perspective, this latter statement is incorrect. Industrialization did not clarify the relationship between economic growth and urbanization; instead, industrialization, and capitalism both transformed and greatly strengthened this relationship to the point where the dynamics became fundamentally different from the growth processes of political cities, in the sense that "more is different" (Anderson, 1972). Nevertheless, we suggest that further attention to non-economic agglomeration processes can not only help explain urban growth in the past, but may also shed light on the variety of urban growth trajectories in the contemporary world.

\section{THE CITY AS ONE THING: A CONTAINER FOR "ENERGIZED CROWDING"}

The concept of cities as places of intensive social interaction"energized crowding" in the words of [Kostof (1991), p. 37] -is shared by both of the dominant definitions of cities and urbanism (Smith, 2019). Furthermore, processes of social interaction operate at a deeper or more fundamental level than the economic and political drivers of urban growth reviewed above, and they can be considered as generative forces for the growth of both economic and political cities. Our argument draws on a wide range of social-science scholarship on this topic.

Population size, density and heterogeneity have long been recognized as fundamental properties of urban settlements (Wirth, 1938; Bairoch, 1988; Angel et al., 2016). ${ }^{3}$ This socioeconomic and cultural heterogeneity in turn facilitates

\footnotetext{
${ }^{3}$ Here we intend density to mean that urban settlements have higher densities than settlements in their hinterland; we make mo judgment about the absolute level of density that may characterize an urban settlement.
}

the plethora of interactions (intentional or serendipitous, fleeting, and consequential, anonymous or long-lasting, driven by economic imperatives or sustained by shared ideological commitments) that make urban life sociologically distinct (Jacobs, 1961; Fischer, 1975). It is this crowding-and the creative, inventive and innovative possibilities which it realizesthat in turn generates growth and change (Glaeser, 2011). Storper and [Storper and Venables (2004), p. 31] have analyzed the mechanism through which "energized crowding" occurs. They call this, "the most fundamental aspect of proximity: face-to-face contact." Although their analysis of the role of face-to-face interaction in urban agglomeration is set firmly within the economic geography approach that ignores political cities and pre-modern societies, at least three of their four "basic functions" of face-to-face contact apply to pre-modern societies: communication technology; trust and incentives in relationships; and screening and socializing. Their fourth function-"rush and motivation"-is more difficult to evaluate for pre-modern contexts.

The perspective that all cities-across eras, geographies, and cultures-share a core of fundamental socioeconomic processes as well as certain predictable quantitative properties has recently coalesced into settlement scaling theory (Bettencourt et al., 2007; Bettencourt, 2013; Bettencourt and Lobo, 2016). Settlement scaling theory draws on insights from urban economics, economic geography, and regional science and shares with these disciplines a common explanation for the existence and development of cities as resulting from the interplay between centripetal and centrifugal "forces" (Colby, 1933; Isard, 1956; Fujita et al., 1999; O’Flaherty, 2005). Population size is arguably among the most important determinants and consequents of socioeconomic development and change in societies before the modern era (Carneiro, 2000; Johnson and Earle, 2000). Such relations are known across the sciences as scaling relations, which relate the macroscopic properties of a system-here a city-to its scale, or size (Barenblatt, 1996, 2003; Brock, 1999). For this reason, the systematic study of such relationships in cities is known as urban scaling or settlement scaling.

What is novel about the scaling framework is that it views cities as integrated socio-economic networks of interactions embedded in physical space, and then derives specific quantitative predictions about the relationship between population size, material output and aereal extent of settlements. The social interactions facilitated by physical proximity-and the lower costs associated with such interactions-drive productivity (Bettencourt et al., 2008, 2013; Bettencourt, 2013). These relationship have been statistically investigated not only for modern metropolitan systems (in the United States, Western Europe, Brazil, Japan, India, China and South Africa) but also for Native American farming villages in North America (before the arrival of the Europeans), Pre-Hispanic Andean and Central Mexican settlements, Ancient Greek and Roman cities, Medieval European cities and towns, and cities in Tudor England (Ortman et al., 2014, 2015, 2016; Cesaretti et al., 2016; Hanson and Ortman, 2017; Ortman and Coffey, 2017; Ossa et al., 2017; Cesaretti et al., under review). The results show a striking similarity in scaling relationships, as predicted by the settlement 
scaling framework. Across cultures and history, when human societies create permanent settlements, these grow denser, on average, with growing population. In addition, the increases in economic production and outputs are proportionally greater than the increase in population size. This, in turn, indicates that humans in larger settlements live in socioecological settings that facilitate higher rates of social interaction, relative to smaller settlements in a given context.

Social settings of ongoing face-to-face contact generate processes of trust, incentives, and monitoring that are among the key ingredients of successful community organization (Ostrom, 1990; Sampson, 1999; Bowles and Gintis, 2002). Urban planners are much concerned with finding ways that the urban built environment can foster productive face-to-face interaction (Talen, 1999; Brower, 2011). The observation that neighborhoods are universal features-not just of cities, but of almost all types of large human settlements (Smith, 2010a; Smith et al., 2015) supports the notion that face-to-face interaction is fundamental and important in all kinds of cities, both economic and political.

The city as a facilitator of social learning might ultimately provide one of the most salient sources of continuity among urban forms across space and time. After all, social learning is emblematic of Homo sapiens. The resulting process of cultural adaptation that is responsible for our species' success was facilitated by both population size and social connectedness (Boyd and Richerson, 2005; Henrich, 2015). Urban life is just one manifestation of the way humans have constructed social and physical spaces to exploit their unique abilities to build cumulative culture (Enquist et al., 2008). We should note that not all of the outcomes of energized crowding are positive traits; increased poverty, crime, and social alienation are also products of social interactions in cities.

These observations about the generative role of face-to-face interaction, from a spectrum of academic disciplines, apply equally well to political and economic cities. The urban built environment provides settings for social interaction, whether the parks, cafes, and sidewalks of contemporary cities or the plazas and marketplaces of ancient cities (Stanley et al., 2012). The same processes of communication and exchange take place among the residents of all cities, past and present. These basic interactions are the essence of what is distinctive about cities as human settlements. Their expression in the broad similarities of scaling relationships across time and history has a clear implication: the city as a container for social interactions throughout history and around the world is one thing, not many.

\section{DISCUSSION AND CONCLUSIONS}

Our analysis has implications for identifying more and less productive paths of comparative research of cities and urbanization. The "city as two things" perspective suggests that analyses of urban growth in economic and political cities are best carried out independently because the processes of growth in the two types of city are quite different. Empirical analyses of the rates and mechanisms of growth in past cities can help identify economic cities before the modern epoch. We argue above that economic growth in Imperial Rome was insufficient to generate the agglomeration economies of modern economic cities. But, given the high level of documentation for Roman urbanism, quantitative analyses of Roman urbanism (e.g., Bowman and Wilson, 2011; Jongman, 2016; Hanson and Ortman, 2017; Hanson et al., 2017) provide models that will contribute to a better understanding of the nature of political and economic cities in the ancient world more generally.

Attempts to apply models of growth devised for contemporary economic cities to ancient cities in the absence of extensive quantitative data (e.g., Algaze, 2008, 2018) may be premature. On the other hand, models of modern primate (political) cities (de Long and Shleifer, 1993; Ades and Glaeser, 1995) would appear to be a productive source of insights for understanding ancient political cities. And given the smaller number of such political cities today and their lack of prominence in the literature on growth theory, perhaps the growing research on urban dynamics in pre-modern political cities might help scholars better understand the primate cities that dominat many developing nations today.

Our second perspective-the city as one thing-has great potential for comparative research that draws cases from, and produces insights for, both pre-modern and contemporary cities. For example scholars are beginning to draw parallels between the roles of neighborhoods in ancient and modern cities (Smith, 2010a; Arnauld et al., 2012; Sampson, 2012; Smith et al., 2015). Our analysis suggests that this topic is a particularly fertile one for comparative analysis, given the importance of social interaction and the built environment in neighborhood dynamics. The success of urban scaling research in identifying the predicted scale relationships in ancient settlement systems (see the sources cited above) provides strong empirical support for this perspective.

Productive research comparing pre-modern and contemporary cities needs to avoid two approaches that have long dominated comparisons of ancient and modern social and economic conditions. On the one hand, many social scientists outside of anthropology simply assume that conditions in the past or in non-western societies were similar to conditions today, and thus economic models can be applied directly without modification. This approach is called "modernism" in Classical studies and "formalism" in economic anthropology. Such work tends to be ignored or dismissed by historians and archaeologists because much of it fits the facts so poorly as to be useless. On the other hand, some scholars ("primitivists" in Classics and "substantivists" in economic anthropology) have portrayed the past (and non-western societies) as so radically different from the present that comparisons are impossible (Polanyi et al., 1957; Finley, 1973). Most scholars now see this as a misguided and highly limiting approach to past societies and economies (Smith, 2004; Wilk and Cliggett, 2007).

Our dual answer to the question posed in this paper's title ("one thing or many") can help scholars avoid these problems of misleading comparisons. From the perspective of the forces that create cities and generate urban growth, there are two general types of cities: economic and political. The dynamics of growth and operation of these cities are quite different, and facile comparisons between them will do little to illuminate general processes of urbanization. But from the perspective of the way 
that people interact with one another in delimited urban spaces, all cities are similar; there is only one type of city. The "energized crowding" first identified by [Kostof (1991), p. 37] is one of the universal features of cities, from ancient time to the present (Smith, 2019). The ability of scholars to explain and understand this process of energized crowding may help determine the productivity of comparative urban scholarship in the future, and it may even contribute to the success or failure of cities and urbanization in the future.

\section{AUTHOR CONTRIBUTIONS}

$\mathrm{JL}$ and MS conducted the research and wrote the article.

\section{FUNDING}

This paper was published thanks to OPEN-AIRE funding granted to Francesca Fulminante for the Marie Sklodowska IEF Past-People-Nets 628818 conducted at the University of Roma Tre (2014-2016).

\section{REFERENCES}

Adamic, L. (2011). Unzipping Zipf's law. Nature 474, 164-165. doi: $10.1038 / 474164 a$

Ades, A. F., and Glaeser, E. L. (1995). Trade and circuses: explaining urban giants. Q. J. Econ. 110, 195-227. doi: 10.2307/2118515

Algaze, G. (2008). Ancient Mesopotamia at the Dawn of Civilization: The Evolution of an Urban Landscape. Chicago: University of Chicago Press.

Algaze, G. (2018). Entropic cities: the paradox of urbanism in ancient mesopotamia. Curr. Anthropol. 59, 23-54. doi: 10.1086/695983

Allen, P. (2009). The British Industrial Revolution in Global Perspective. New York, NY: Cambridge University Press. doi: 10.1017/CBO9780511816680

Anderson, P. W. (1972). More is different. Science 177, 392-396. doi: 10.1126/science.177.4047.393

Andreau, J. (1999). Banking and Business in the Roman World. New York, NY: Cambridge University Press.

Angel, S. (2012). Planet of Cities. Cambridge, MA: Lincoln Land Institute.

Angel, S., Blei, A. M., Parent, J., Lamson-Hall, P., Galarza, N., Civco, D. L., et al. (2016). Atlas of Urban Expansion: 2016 Edition Volume 1: Areas and Densities. New York, NY: New York University.

Arnauld, M. C., Manzanilla, L. R., and Smith, M. E. (eds) (2012). The Neighborhood as a Social and Spatial Unit in Mesoamerican Cities. Tucson, AZ: University of Arizona Press.

Bairoch, P. (1988). Cities and Economic Development: From the Dawn of History to the Present. Chicago, IL: University of Chicago Press.

Barenblatt, G. I. (1996). Scaling, Self-Similarity, and INtermediate Asymtotics. New York, NY: Cambridge University Press.

Barenblatt, G. I. (2003). Scaling. New York, NY: Cambridge University Press.

Barthel, S., and Isendahl, C. (2013). Urban gardens, agriculture, and water management: sources of resilience for long-term food security in cities. Ecol. Econom. 86, 224-234. doi: 10.1016/j.ecolecon.2012.06.018

Baumol, W. J. (1990). Entrepreneurship: productive, unproductive, and destructive. J. Polit. Econ. 98, 893-921. doi: 10.1086/261712

Behrens, K., and Bala, A. P. (2013). Do rent-seeking and interregional transfers contribute to Urban primacy in sub-saharan Africa? Papers Reg. Sci. 92, 163-195. doi: 10.1111/j.1435-5957.2011.00400.x

Bettencourt, L. M. A. (2013). The origins of scaling in cities. Science 340, 1438-1441. doi: 10.1126/science.1235823

Bettencourt, L. M. A., and Lobo, J. (2016). Urban scaling in Europe. J. R. Soc. Interf. 13. doi: $10.1098 /$ rsif. 2016.0005

\section{ACKNOWLEDGMENTS}

This paper originated in a public lecture by Smith at the Santa Fe Institute in July, 2013, and the ideas were subsequently developed through conversations and face-to-face interactions. We want to thank Scott Ortman and Luis Bettencourt for many productive discussions of cities and urbanization processes. We thank the Santa Fe Institute and the ASU-SFI Center for Biosocial Complex Systems for funding the Working Group in Urban Scaling, which provided the opportunity for us to develop these ideas. Smith wants to acknowledge the always stimulating faceto-face interaction with his colleagues in the research project, Urbanization through the Ages: Neighborhoods, Open Spaces, and Urban Life in the School of Human Evolution \& Social Change at ASU. Breandán Ó’Huallacháin helped Smith wade into the murky waters of agglomeration economies with discussions and bibliographic suggestions. We thank Scott Ortman, Barbara Stark, and Abigail York for helpful comments on an earlier draft of this paper. Presentations at the University of British Columbia and Dartmouth College contributed to the refinement of our ideas.

Bettencourt, L. M. A., Lobo, J., Helbing, D., Kühnert, C., and West, G. B. (2007) Growth, innovation, scaling, and the pace of life in cities. Proc. Natl. Acad. Sci. U.S.A. 104, 7301-7306. doi: 10.1073/pnas.0610172104

Bettencourt, L. M. A., Lobo, J., and West, G. B. (2008). Why are large cities faster? Universal scaling and self-similarity in urban organization and dynamics. Eur. Phys. J. B 63, 285-293. doi: 10.1140/epjb/e2008-00250-6

Bettencourt, L. M. A., Lobo, J., and Youn, H. (2013). The Hypothesis of Urban Scaling: Formalization, Implications and Challenges. Santa Fe, NM: Santa Fe Institute.

Bjork, G. J. (1999). The Way it Worked and Why it Won't: Structural Change and the Slowdown of U.S. Economic Growth. London: Praeger.

Black, D., and Henderson, V. (1999). A theory of urban growth. J. Polit. Econ. 107, 252-284. doi: 10.1086/250060

Bowles, S., and Gintis, H. (2002). Social capital and community Governance. Econ. J. 112, F419-F436. doi: 10.1111/1468-0297.00077

Bowman, A. K., and Wilson, A. (eds) (2011). Settlement, Urbanization, and Population. New York, NY: Oxford University Press.

Boyd, R., and Richerson, P. J. (2005). The Origin and Evolution of Cultures. New York, NY: Oxford University Press.

Braudel, F. (1982). The Wheels of Commerce. New York, NY: Harper and Row.

Brock, W. A. (1999). Scaling in economics: a reader's guide. Indust. Corporate Change 8, 409-446. doi: 10.1093/icc/8.3.409

Brower, S. N. (2011). Neighbors and Neighborhoods: Elements of Successful Community Design. Chicago, IL: APA Planners Press.

Burkai, H. (1969). A formal outline of a smithian growth model. Q. J. Econ. 83, 396-414. doi: 10.2307/1880528

Carneiro, R. L. (2000). The transition from quantity to quality: a neglected causal mechanism in accounting for social evolution. Proc. Natl. Acad. Sci. U.S.A. 97, 12926-12931. doi: 10.1073/pnas.240462397

Cesaretti, R., Bettencourt, L. M. A., Lobo, J., Ortman, S., and Smith, M. E. (2016). Population-area relationship in medieval european cities. PLOS ONE 11:e162678. doi: 10.1371/journal.pone.0162678

Christaller, W. (1966). Central Places in Southern Germany. Englewood Cliffs, NJ: Prentice-Hall.

Clarke, S. (1993). “The Pre-Industrial City in Roman Britain,” in Theoretical Roman Archaeology: First Conference Proceedings, ed E. Scott. (Avebury: Aldershot), 49-66. doi: 10.16995/TRAC19914966

Colby, C. C. (1933). Centrifugal and centripetal forces in urban geography. Ann. Assoc. Am. Geogr. 23, 1-20. doi: 10.1080/000456033093 57110 
Congress for the New Urbanism (1996). Charter of the New Urbanism. Congress for the New Urbanism. Available online at: http://www.cnu.org/charter

Cowgill, G. L. (2004). Origins and development of urbanism: archaeological approaches. Annu. Rev. Anthropol. 33, 525-549. doi: 10.1146/annurev.anthro.32.061002.093248

de Long, J. B., and Shleifer, A. (1993). Princes and merchants: european city growth before the industrial revolution. J. Law Econ. 36, 671-702. doi: 10.1086/4 67294

Duranton, G., and Puga, D. (2004). "Micro-Foundation of Urban Agglomeration Economies," in Handbook of Regional and Urban Economics, eds J. V. Henderson and J. F. Thisse (Amsterdam: Elsevier), 2064-2117. doi: 10.1016/S1574-0080(04)80005-1

Enquist, M., Ghirlanda, S., Jarrick, A., and Wachtmeister, C. A. (2008). Why does human culture increase exponentially? Theor. Popul. Biol. 74, 46-55. doi: $10.1016 /$ j.tpb.2008.04.007

Erdkamp, P. (2016). Economic growth in the Roman Mediterranean world: an early good-bye to Malthus? Explor. Econ. Hist. 60, 1-20. doi: 10.1016/j.eeh.2015.11.004

Feinman, G. M., and Garraty, C. P. (2010). Preindustrial markets and marketing: archaeological perspectives. Annu. Rev. Anthropol. 39, 167-191. doi: 10.1146/annurev.anthro.012809.105118

Finley, M. I. (1973). The Ancient Economy. Berkeley, CA: University of California Press.

Fischer, C. S. (1975). Toward a subcultural theory of Urbanism. Am. J. Sociol. 80, 1319-1341. doi: 10.1086/225993

Fisher, K. D. (2009). Placing social interaction: an integrative approach to analyzing past built environments. J. Anthr. Archaeol. 28, 439-457. doi: 10.1016/j.jaa.2009.09.001

Fletcher, R. (2009). Low-density, agrarian-based urbanism: a comparative view. Insights 2:19.

Fox, R. G. (1977). Urban Anthropology: Cities in their Cultural Settings. Englewood Cliffs: Prentice-Hall.

Fujita, M., Krugman, P., and Venables, A. J. (1999). The Spatial Economy: Cities, Regions, and International Trade. Cambridge: MIT Press.

Garraty, C. P., and Stark, B. L. (eds) (2010). Archaeological Approaches to Market Exchange in Ancient Societies. Boulder, CO: University Press of Colorado.

Gerth, H. H., and Mills, C. W. (eds) (1946). From Max Weber: Essays in Sociology. New York, NY: Oxford University Press.

Glaeser, E. L. (2011). The Triumph of Cities: How our Greatest Invention Makes us Richer, Smarter, Greener, Healthier, and Happier. New York, NY: Penguin.

Gleeson-White, J. (2012). Double Entry: How the Merchants of Venice Created Modern Finance. New York, NY: Norton.

Greene, K. (2000). technological innovation and economic progress in the ancient world: M. I. finley re-considered. Econ. History Rev. 53, 29-59. doi: 10.1111/1468-0289.00151

Hakim, B. S. (2012). Neighborhood test design based on historic precedents. Int. J. Architect. Res. 6, 135-148. doi: 10.26687/archnet-ijar. v6i2.89

Hall, P. (1998). Cities in Civilization. New York, NY: Pantheon.

Hanson, J. W., and Ortman, S. G. (2017). A systematic method for estimating the populations of greek and roman settlements. J. Roman Archaeol. 30, 301-324. doi: 10.1017/S1047759400074134

Hanson, J. W., Ortman, S. G., and Lobo, J. (2017). Urbanism and the division of labour in the roman empire. J. R. Soc. Interf. 14:20170367. doi: 10.1098/rsif.2017.0367

Healy, K. (2017). F** k Nuance. Sociol. Theor. 35, 118-127. doi: $10.1177 / 0735275117709046$

Henrich, J. (2015). The Secret of Our Success: How Learning from Others Drove Human Evolution, Domesticated our Species and Made us Smart. Princeton, NJ: Princeton University Press. doi: 10.2307/j.ctvc77f0d

Hipp, J. R., Faris, R. W., and Boessen, A. (2012). Measuring 'Neighborhood': constructing network neighborhoods. Soc. Netw. 34, 128-140. doi: 10.1016/j.socnet.2011.05.002

Hopkins, K. (1978). "Economic Growth and Towns in Classical Antiquity," in Towns in Societies: Essays in Economic HIstory and Historical Sociology, eds P. Abrams and E.A. Wrigley (Cambridge: University Press), 35-77.

Hoselitz, B. (1955). Generative and parasitic cities. Econ. Dev. Cult. Change 3, 278-294. doi: 10.1086/449689
Hudson, M. (2010). "Entrepreneurs: From the Near Eastern Takeoff to the Roman Collapse," in The Invention of Enterprise: Entrepreneurship from Ancient Mesopotamia to Modern Times, eds D.S. Landes, J. Mokyr, and W.J. Baumol (Princeton, NJ: Princeton University Press), 8-39. doi: 10.1515/9781400833580-005

Isard, W. (1956). Location and Space-economy: A General Theory Relating to Industrial Location, Market Areas, Land Use, Trade, and Urban Structure. Cambridge: MIT Press.

Jacobs, J. (1961). The Death and Life of Great American Cities. New York, NJ: Random House.

Jacobs, J. (1969). The Economy of Cities. New York, NJ: Vintage Books.

Johnson, A. W., and Earle, T. K. (2000). The Evolution of Human Societies: From Foraging Group to Agrarian State. Stanford, CA: Stanford University Press.

Jones, C. I., and Romer, P. M. (2010). The new kaldor facts: ideas, institutions, population, and human capital. Am. Econ. J. 2, 224-245. doi: $10.1257 / \mathrm{mac} .2 .1 .224$

Jongman, W. M. (2012). "Roman Economic Change and the Antonine Plague: Endogenous, Exogenous, or What?" in L'Impatto della "Peste Antonina", ed E. Lo Cascio (Bari: Edipuglia), 253-263.

Jongman, W. M. (2016). "Italian Urbanization and Roman Economic Growth,” in L'Italia dei Flavi: Atti del convegno, Roma 4-5 octobre 2012, eds L. Capogrossi Colognesi, E. Lo Cascio (Rome: L'Erma di Bretschneider), 105-117.

Kelly, M. (1997). The dynamics of smithian growth. Q. J. Econ. 112, 939-964. doi: $10.1162 / 003355397555398$

Kostof, S. (1991). The City Shaped: Urban Patterns and Meanings Through History. Boston, MA: Bullfinch.

Langton, J. (1975). Residential patterns in pre-industrial cities: some case studies from seventeenth-century Britain. Transat. Inst. Br. Geogr. 65, 1-27. doi: $10.2307 / 621607$

Lloyd, P. E., and Dicken, P. (1972). Location in Space: A Theoretical Approach to Economic Geography. New York, NY: Harper and Row.

Lucas, R. E. Jr. (1988). On the mechanics of economic development. J. Monetar. Econ. 229, 3-42. doi: 10.1016/0304-3932(88)90168-7

Marcus, J. (1983). “On the Nature of the Mesoamerican City," in Prehistoric Settlement Patterns: Essays in Honor of Gordon R. Willey, eds E. Z. Vogt and R. M. Leventhal (Albuquerque, MA: University of New Mexico Press), 195-242.

Morris, I. (2004). Economic growth in ancient greece. J. Inst. Theor. Econ. 160, 709-742. doi: 10.1628/0932456042776050

Mumford, L. (1961). The City in History: Its Origins, Its Transformations, and Its Prospects. New York, NY: Harcourt, Brace, Jovanovich.

Noreña, C. F. (2014). "Urban Systems in the Han and Roman Empires: State Power and Social Control," in State Power in Ancient China and Rome, ed W. Scheidel (New York, NY: Oxford University Press), 181-203.

North, D. C. (1991). Institutions. J. Econ. Perspect. 5, 97-112. doi: $10.1257 /$ jep.5.1.97

O'Flaherty, B. (2005). City Economics. Cambridge: Harvard University Press.

Ortman, S. G., Cabaniss, A. H. F., Sturm, J. O., and Bettencourt, L. M. A. (2014). The pre-history of urban scaling. PLoS ONE 9:e87902. doi: 10.1371/journal.pone.0087902

Ortman, S. G., Cabaniss, A. H. F., Sturm, J. O., and Bettencourt, L. M. A. (2015). Settlement scaling and increasing returns in an ancient society. Sci. Adv. 1:e1400066. doi: 10.1126/sciadv.1400066

Ortman, S. G., and Coffey, G. D. (2017). Settlement scaling in middle-range societies. Am. Antiquity 82, 662-682. doi: 10.1017/aaq.2017.42

Ortman, S. G., Davis, K. E., Lobo, J., Smith, M. E., Bettencourt, L. M. A., and Trumbo, A. (2016). Settlement scaling and economic change in the central andes. J. Archaeol. Sci. 73, 94-106. doi: 10.1016/j.jas.2016.07.012

Ossa, A., Smith, M. E., and Lobo, J. (2017). The size of plazas in mesoamerican cities: a quantitative analysis and social interpretation. Latin Am. Antiquity 28, 457-475. doi: 10.1017/laq.2017.49

Ostrom, E. (1990). Governing the Commons: The Evolution of Institutions for Collective Action. New York, NY: Cambridge University Press.

O'Sullivan, A. (2011). Urban Economics. New York, NY: McGraw-Hill.

Parkins, H. M. (ed) (1997). Roman Urbanism: Beyond the Consumer City. New York, NY: Routledge.

Persson, K. G., and Sharp, P. (2015). An Economic History of Europe: Knowledge, Institutions and Growth, 600 to the Present. New York, NY: Cambridge University Press. 
Polanyi, K., Arensburg, C. M., and Pearson, H. W. (eds) (1957). Trade and Market in the Early Empires. Chicago, IL: Henry Regnery Co.

Pryor, F. L. (2005). Economic Systems of Foraging, Agricultural, and Industrial Societies. New York, NY: Cambridge University Press.

Rapoport, A. (1973). The city of tomorrow, the problems of today and the lessons of the past. DMG-DRS J. 7, 256-259.

Redfield, R., and Singer, M. (1954). The cultural role of cities. Econ. Dev. Cult. Change 3, 53-73. doi: $10.1086 / 449678$

Romer, P. M. (1990). Endogenous technological change. J. Polit. Economy 98, S71-S1021. doi: $10.1086 / 261725$

Sampson, R. J. (1999). "What Community Supplies," in Urban Problems and Community Development, eds R. F. Ferguson and W. T. Dickens (Washington, DC: Brookings Institution Press), 241-292.

Sampson, R. J. (2012). Great American City: Chicago and the Enduring Neighborhood Effect. Chicago, IL: University of Chicago Press.

Scheidel, W. (2004). Demographic and economic development in the ancient mediterranean world. J. Inst. Theor. Econ. 160, 743-757. doi: $10.1628 / 0932456042776069$

Scott, A. J., and Storper, M. (2015). The nature of cities: the scope and limits of Urban Theory. Int. J. Urban Reg. Res. 39, 1-15. doi: 10.1111/1468-2427.12134

Sjoberg, G. (1960). The Preindustrial City: Past and Present. New York, NY: The Free Press.

Smith, A. (1979). The Wealth of Nations, Books I-III. Baltimore, MD: Penguin.

Smith, M. E. (2004). The archaeology of ancient state economies. Ann. Rev. Anthropol. 33, 73-102. doi: 10.1146/annurev.anthro.33.070203.144016

Smith, M. E. (2010a). The archaeological study of neighborhoods and districts in ancient cities. J. Anthropol. Archaeol. 29, 137-154. doi: 10.1016/j.jaa.2010.01.001

Smith, M. E. (2010b). Sprawl, Squatters, and sustainable cities: can archaeological data shed light on modern urban issues? Cambridge Archaeol. J. 20, 229-253. doi: $10.1017 /$ S0959774310000259

Smith, M. E. (2016). "How Can Archaeologists Identify Early Cities: Definitions, Types, and Attributes," in Eurasia at the Dawn of History: Urbanization and Social Change, eds M. Fernández-Götz and D. Krausse (New York, NY: Cambridge University Press), 153-168. doi: 10.1017/9781316550328.010

Smith, M. E. (2018). The Importance of a Comparative Perspective in the Study of Ancient Economies. Bonn: Habelt-Verlag.

Smith, M. E. (2019). "The Generative Role of Settlement Aggregation and Urbanization," in Coming Together: Comparative Approaches to Population Aggregation and Early Urbanization, ed A. Gyucha. (Albany: State University of New York Press), 37-58.

Smith, M. E., Engquist, A., Carvajal, C., Johnston, K., Young, A., Algara, M., et al. (2015). Neighborhood formation in semi-Urban settlements. J. Urbanism 8, 173-198. doi: 10.1080/17549175.2014.896394

Smith, M. E., Stark, B. L., Chuang, W.-C., Dennehy, T., Harlan, S. L., KampWhittaker, A., et al. (2016). Comparative methods for premodern cities: coding for governance and class mobility. Cross-Cult. Res. 50, 415-451. doi: $10.1177 / 1069397116665824$

Solow, R. M. (1956). A contribution to the theory of economic growth. Q. J. Econ. 70, 65-94. doi: 10.2307/1884513

Stanley, B. W., Dennehy, T., Smith, M. E., Stark, B. L., York, A., Cowgill, G. L., et al. (2016). Service access in premodern cities: an exploratory comparison of spatial equity. J. Urban History 42, 121-144. doi: 10.1177/0096144214 566969

Stanley, B. W., Stark, B. L., Johnston, K., and Smith, M. E. (2012). Urban open spaces in historical perspective: a transdisciplinary typology and analysis. Urban Geogr. 33, 1089-1117. doi: 10.2747/0272-3638.33. 8.1089

Stark, B. L., Boxt, M. A., Gasco, J., González Lauck, R. B., Balkin, J. D. H., Joyce, A. A., et al. (2016). Economic growth in mesoamerica: obsidian consumption in the coastal lowlands. J. Anthropol. Archaeol. 41, 263-282. doi: 10.1016/j.jaa.2016.01.008

Storper, M. (2013). Keys to the City: How Economics, Institutions, Social Interactions, and Politics Shape Development. Princeton, NJ: Princeton University Press.

Storper, M., and Venables, A. J. (2004). Buzz: face-to-face contact and the urban economy. J. Econ. Geogr. 4, 351-370. doi: 10.1093/jnlecg/lbh027

Stull, W. J. (1986). The Urban economics of adam smith. J. Urban Econ. 20, 291-311. doi: 10.1016/0094-1190(86)90021-5

Swan, T. W. (1956). Economic growth and capital accumulation. Econ. Redord 32, 334-361. doi: 10.1111/j.1475-4932.1956.tb00434.x

Talen, E. (1999). Sense of community and neighbourhood form: an assessment of the social doctrine of New Urbanism. Urban Stud. 36, 1361-1379. doi: 10.1080/0042098993033

Temin, P. (2013). The Roman Market Economy. Princeton, NJ: Princeton University Press.

Trigger, B. G. (1972). "Determinants of Urban Growth in Pre-Industrial Societies," in Man, Settlement, and Urbanism, eds P. J. Ucko, R. Tringham, and G. W. Dimbleby (Cambridge: Schenkman), 575-599.

Vance, J. E. J. (1971). Land assignment in the precapitalist, capitalist, and postcapitalist city. Econ. Geogr. 47, 101-120. doi: 10.2307/143040

Weber, M. (1958). The City. Transl. by D. Martindale and G. Neuwirth. New York, NY: Free Press.

Weil, D. N. (2008). Economic Growth. New York, NY: Addison Wesley.

Wheatley, P. (1971). The Pivot of the Four Quarters: A Preliminary Enquiry into the Origins and the Character of the Ancient Chinese City. Chicago, IL: Aldine.

Wilk, R. R., and Cliggett, L. C. (2007). Economies and Cultures: Foundations of Economic Anthropology. Boulder, CO: Westview Press.

Wirth, L. (1938). Urbanism as a way of life. Am. J. Sociol. 44, 1-24. doi: $10.1086 / 217913$

Wrigley, E. A. (1978). "Parasite or Stimulus: The Town in a Pre-Iindustrial Economy," in Towns in Societies: Essays in Economic History and Historical Sociology, eds P. Abrams and E. A. Wrigly (Cambridge: Cambridge University Press), 295-309.

York, A., Smith, M. E., Stanley, B., Stark, B. L., Novic, J., Harlan, S. L., et al. (2011). Ethnic and class clustering through the ages: a transdisciplinary approach to urban social patterns. Urban Stud. 48, 2399-2415. doi: $10.1177 / 0042098010384517$

Youn, H., Bettencourt, L. M., Lobo, J., Strumsky, D., Samaniego, H., and West, G. B. (2016). Scaling and universality in Urban economic diversification. J. R. Soc. Interface 13:20150937. doi: 10.1098/rsif.2015.0937

Conflict of Interest Statement: The authors declare that the research was conducted in the absence of any commercial or financial relationships that could be construed as a potential conflict of interest.

Copyright (C) 2019 Smith and Lobo. This is an open-access article distributed under the terms of the Creative Commons Attribution License (CC BY). The use, distribution or reproduction in other forums is permitted, provided the original author(s) and the copyright owner(s) are credited and that the original publication in this journal is cited, in accordance with accepted academic practice. No use, distribution or reproduction is permitted which does not comply with these terms. 